\title{
Incidental Syringomas of the Scalp in a Patient with Scarring Alopecia
}

\author{
Kristyn Deen Claudia Curchin Jason Wu \\ Department of Dermatology, Princess Alexandra Hospital, Brisbane, Qld., Australia
}

\section{Key Words}

Syringoma $\cdot$ Scalp $\cdot$ Alopecia $\cdot$ Lichen planopilaris

\begin{abstract}
Syringomas are benign adnexal neoplasms of eccrine lineage, which occur most commonly in the periorbital region in middle-aged females. These cutaneous lesions rarely occur on the scalp, are typically asymptomatic and are predominantly of cosmetic significance. Involvement of the scalp may be indistinguishable from that of scarring alopecia. We present an unusual case of clinically inapparent syringomas occurring on the scalp of a 56-year-old female with alopecia who was subsequently diagnosed with lichen planopilaris after repeated scalp biopsy. In patients with unexplained hair loss, or in cases that are refractive to treatment, clinicians should perform scalp biopsy to exclude the diagnosis of rare neoplastic lesions like syringomas and to diagnose associated conditions.

(c) 2015 S. Karger AG, Basel
\end{abstract}

\section{Introduction}

Syringoma is a benign adnexal neoplasm of either apocrine or eccrine lineage with predominantly ductal differentiation [1]. Syringomas appear clinically as smooth, firm, skincoloured/pink papules, commonly occurring in multiplicity. The lesions are usually 1-3 mm in diameter with a symmetrical distribution and are usually asymptomatic. Syringomas appear more commonly in women than men, with an increased incidence in Asian populations, and have been associated with Down syndrome [2]. Syringomas may occur on any site of the body, but lesions favour the periorbital area, particularly the eyelids, and rarely occur on the scalp producing scarring alopecia [1]. We describe the unusual presentation of clinically inapparent syringomas occurring on the scalp of a 56-year-old female with scarring alopecia. 
Deen et al.: Incidental Syringomas of the Scalp in a Patient with Scarring Alopecia

\section{Case Report}

A 56-year-old female presented with a 6-month history of an insidiously progressive loss of frontal scalp hair. The patient reported some associated mild scalp pruritus. The patient denied any trauma to the hair and had no known medical or surgical history of any kind including thyroid/autoimmune disease. She did not take any regular medications, but did have an allergy to sulphur. She had a family history of alopecia with her mother also suffering hair loss.

On examination, bilateral thinning of the frontoparietal scalp hair was evident (fig. 1). This affected the left side more than the right and was associated with decreased visible follicular openings, perifollicular scaling and erythema. There were 2 areas involved - a $12 \times$ $2.5 \mathrm{~cm}$ area of the left parietal scalp and a $4 \times 1.5 \mathrm{~cm}$ area on the right parietal scalp. The occipital and vertex regions were not involved. No associated nail changes, oral mucosal changes or cutaneous/acral lesions were noted. Systemic examination was otherwise normal. The initial clinical impression was that of lichen planopilaris.

Her subsequent full blood count, thyroid function tests, electrolytes and liver/renal function were all normal. She had an anti-nuclear antibody titre of 160, but otherwise, autoimmune screening was negative. Her urine was negative for infection/casts, and the protein/creatinine ratio was within normal limits.

Two 4-mm punch biopsies of the left anterior scalp revealed a slight reduction of terminal hair with focal perifollicular fibrosis and occasional collections of perivascular lymphocytes. No lichenoid changes were seen. There were large numbers of syringomatous elements in the upper dermis.

Further comparative biopsies were taken 2 months later, from clinically normal scalp and normal hair-bearing skin of the arm, to determine whether the syringomas were the primary cause of alopecia or an incidental finding. Two 4-mm punch biopsies were taken from the scalp vertex. One scalp biopsy showed perifollicular fibrosis and no syringomatous elements, but the second biopsy from normal scalp showed a reduction in terminal hairs with perifollicular fibrosis/inflammation with extension of the lymphocytes into the follicular epithelium in the upper half of the hair follicles. This biopsy again showed no lichenoid reaction within the epidermis but compound and distorted hair follicles were present in the upper parts of the biopsy as well as syringomatous elements (fig. 2, fig. 3). The biopsy specimen of the left arm showed completely normal skin.

Based on these findings, the cause of the alopecia was deemed to be unlikely secondary to the syringomas, given that the biopsies of the clinically normal scalp showed scarring alopecia. The diagnosis of lichen planopilaris was made, with coincidental syringomas.

She was initially treated with mometasone lotion daily to the scalp with no effect and thus was then treated with multiple intradermal steroid injections to the scalp every 6-8 weeks with minimal improvement. The patient is currently on plaquenil $200 \mathrm{mg}$ daily and has noticed obvious hair regrowth, with only subtle areas of hair loss remaining.

\section{Discussion}

Syringoma is a benign tumour derived from acrosyringium, the intraepidermal portion of eccrine/apocrine sweat ducts. They are largely asymptomatic tumours and are predominantly of cosmetic significance. Syringomas are typically localized to the eyelids of middleaged women; however, other sites include the ventral surface of the trunk, forehead, neck, axillae, abdomen and rarely the penis, vulva, buttocks, moustache area and scalp [1]. A clas- 
sification scheme has been proposed by Friedman and Butler [2] identifying 4 variants of syringoma: a localized form, a form associated with Down syndrome, a familial form and a generalized form (encompassing multiple and eruptive syringomas). Treatment modalities are based on cosmetic concerns including carbon dioxide laser, excision, dermabrasion, electrodessication and curettage [3].

Based on reports in the literature, we identified 11 previous cases of syringoma of the scalp [4-13]. In 8 of these cases, the scalp syringomas were reported as the cause of the patient's associated alopecia (table 1). Conversely, in the other 3 reports of scalp syringoma, 2 cases were not associated with alopecia at all $[9,13]$, while 1 case was reported as an incidental syringoma in a patient with known androgenic alopecia [12] (table 1). In our case, the initial clinical impression was that of alopecia associated with lichen planopilaris, and subsequent biopsy then showed the incidental finding of syringoma.

In the past, some authors have suggested that scalp syringoma was associated with scarring alopecia in patients due to a reactive proliferation/fibrosis secondary to syringoma cells causing pressure necrosis of hair follicles and mesenchymal stromal changes unfavorable to hair growth [7]. However, based on previously reported cases, it is clear that scalp syringoma can be a primary cause of alopecia, an incidental finding without alopecia or an incidental finding in patients with another alopecia-causing condition, as in our case with lichen planopilaris. Interestingly, other reports have also suggested some eccrine proliferations causing alopecia with associated syringoma-like histological changes $[14,15]$.

In summary, whilst syringoma of the scalp is rarely reported, it has been described both as an incidental finding and also as a direct cause of alopecia. Interestingly, in our case, syringoma was not clinically apparent until histological examination of the scalp biopsies. Thus, whilst our case demonstrates an incidental scalp syringoma associated with lichen planopilaris, in cases where a cause of alopecia is uncertain, it is important to undertake scalp and other cutaneous biopsies to exclude a neoplastic process and to make a definitive diagnosis - especially in the absence of another cutaneous disease. Furthermore, a surgical biopsy of the scalp to an adequate depth should be performed in these patients to confirm the presence or absence of neoplasia and to avoid misdiagnosis of the malignant analog, syringomatous carcinoma, which can also be clinically unsuspected.

\section{Statement of Ethics}

The authors state that the patient gave their informed consent. The research complies with all ethical guideline for human studies.

\section{Disclosure Statement}

The authors have no competing/conflicts of interest and no funding sources to disclose.

\section{References}

1 Ghanadan A, Khosravi M: Cutaneous syringoma: a clinicopathologic study of 34 new cases and review of the literature. Indian J Dermatol 2013;58:326.

- Friedman SJ, Butler DF: Syringoma presenting as milia. J Am Acad of Dermatol 1987;16:310-314.

-3 Drazin M: Hereditary syringomas: a case report. Dermatol Online J 2004;10:19. 
Deen et al.: Incidental Syringomas of the Scalp in a Patient with Scarring Alopecia

4 Noble JP, Lessana-Leibowitch M, Sedel D, Guillemette J, Cadot M, Hewitt J: Scalp syringoma with lichen sclerosus-like cicatricial alopecia. Ann Dermatol Venereol 1979;106:275-277.

5 Shelley WB, Wood MG: Occult syringomas of scalp associated with progressive hair loss. Arch Dermatol 1980;116:843-844.

6 Dupre A, Bonafe JL, Christol B: Syringomas as a causative factor for cicatricial alopecia. Arch Dermatol 1981;117:315.

7 Neuman KM, Burnett JW: Alopecia associated with syringomas. J Am Acad Dermatol 1985;13:528-529.

8 Pujol R, Moreno A, Gonzalez MJ, Moraofgas JM: Syringoma of the scalp. Ann Dermatol Venereol 1986;113:693-695.

$\$ 9$ Sanchez Yus E, Lopez Correcher B, Requena Caballero L, Vazquez Lopez F: Syringoma of the scalp under a seborrhoeic wart. Ann Dermatol Venereol 1987;114:707-708.

10 Helm TN, Guitart J, Bergfeld WF, Benedetto E: Occult syringoma associated with alopecia. Int J Dermatol 1992;31:437-438.

11 Tsoitis G, Asvesti C, Mandinaos C, Lambroudi M, Hatzibougias J, Babi A: Cicatricial alopecia of the scalp with histological aspect of syringoma. Ann Dermatol Venereol 1992;119:919-922.

12 Kumaran MS, Kanwar A: Multiple syringomas of the forehead and scalp: an unusual presentation. Indian J Dermatol 2005;50:171-172.

13 Silva CS, Souza MB, Lima KAS, et al: Generalized eruptive syringoma: case report (in Portuguese). Dermatol Online J 2009;15:7.

14 Trozak DJ, Wood C: Occult eccrine sweat duct hamartoma and cicatricial scalp alopecia. Cutis 1984;34:475477.

15 Mehregan AH, Mehregan DA: Syringoma-like sweat-duct proliferation in scalp alopecias. J Cutan Pathol 1990;17:355-357. 


\section{Case Reports in Dermatology}

\begin{tabular}{l|l}
\hline \multicolumn{2}{l|}{ Case Rep Dermatol 2015;7:171-177 } \\
\hline DOI: $10.1159 / 000437416$ & $\begin{array}{l}\text { C) 2015 S. Karger AG, Basel } \\
\text { www.karger.com/cde }\end{array}$ \\
\hline
\end{tabular}

Deen et al.: Incidental Syringomas of the Scalp in a Patient with Scarring Alopecia

Table 1. Clinical details of previously reported cases of scalp syringoma

\begin{tabular}{|c|c|c|c|c|c|c|}
\hline Article & $\begin{array}{l}\text { Age, } \\
\text { year }\end{array}$ & Sex & $\begin{array}{l}\text { Location on } \\
\text { scalp }\end{array}$ & Clinical appearance of scalp & $\begin{array}{l}\text { Other cutaneous mani- } \\
\text { festations }\end{array}$ & $\begin{array}{l}\text { Histological } \\
\text { diagnosis }\end{array}$ \\
\hline $\begin{array}{l}\text { Noble et al., } \\
1979[4]\end{array}$ & 68 & M & Scalp vertex & $\begin{array}{l}3 \times 1.5 \mathrm{~cm} \text { area of scarring } \\
\text { alopecia with few purpuric } \\
\text { spots/crusty lesions }\end{array}$ & Nil & Syringoma \\
\hline $\begin{array}{l}\text { Shelley and } \\
\text { Wood, } \\
1980[5]\end{array}$ & 57 & $\mathrm{~F}$ & Diffuse & $\begin{array}{l}\text { Diffuse thinning of hair only } \\
\text { with loss of hair follicles }\end{array}$ & Nil & Syringoma \\
\hline $\begin{array}{l}\text { Dupre et al., } \\
1981[6]\end{array}$ & 47 & M & Not reported & $\begin{array}{l}\text { Scarring alopecia with mi- } \\
\text { cronodular appearance and } \\
\text { scalp erythema }\end{array}$ & $\begin{array}{l}\text { Associated generalized } \\
\text { eruptive syringomas of } \\
\text { eyelids }\end{array}$ & Syringoma \\
\hline $\begin{array}{l}\text { Neuman and } \\
\text { Burnett, } \\
1985 \text { [7] }\end{array}$ & 58 & $\mathrm{~F}$ & Diffuse & $\begin{array}{l}\text { Loss of hair follicles, no } \\
\text { scarring or other eruptions }\end{array}$ & Nil & Syringoma \\
\hline $\begin{array}{l}\text { Pujol et al., } \\
1986[8]\end{array}$ & 46 & $\mathrm{~F}$ & $\begin{array}{l}\text { Right temporal- } \\
\text { occipital region }\end{array}$ & $\begin{array}{l}1.5-\mathrm{cm} \text { area of circum- } \\
\text { scribed scarring alopecia } \\
\text { with micronodular appear- } \\
\text { ance }\end{array}$ & Nil & Syringoma \\
\hline $\begin{array}{l}\text { Sanchez Yus } \\
\text { et al., } \\
1987 \text { [9] }\end{array}$ & 48 & M & $\begin{array}{l}\text { Right parietal } \\
\text { area }\end{array}$ & $\begin{array}{l}0.7 \times 0.5 \mathrm{~cm} \text { brown papule } \\
\text { with no associated alopecia }\end{array}$ & Nil & $\begin{array}{l}\text { Seborrhoeic } \\
\text { wart with } \\
\text { associated } \\
\text { syringoma }\end{array}$ \\
\hline $\begin{array}{l}\text { Helm et al., } \\
1992[10]\end{array}$ & 50 & $\mathrm{~F}$ & Diffuse & Diffuse alopecia of scalp & Nil & Syringoma \\
\hline \multirow[t]{2}{*}{$\begin{array}{l}\text { Tsoitis et al., } \\
1992[11]\end{array}$} & 71 & $\mathrm{~F}$ & $\begin{array}{l}\text { Parietal- } \\
\text { occipital region }\end{array}$ & Scarring alopecia & Eyelid papules & Syringoma \\
\hline & 32 & $\mathrm{~F}$ & $\begin{array}{l}\text { Parietal- } \\
\text { occipital region }\end{array}$ & Scarring alopecia & Nil & Syringoma \\
\hline $\begin{array}{l}\text { Kumaran and } \\
\text { Kanwar, } \\
2005 \text { [12] }\end{array}$ & 55 & M & Not reported & $\begin{array}{l}\text { Numerous discrete } 1-2 \mathrm{~mm} \\
\text { brown papules with diffuse } \\
\text { distribution in both bald and } \\
\text { hair-bearing scalp regions }\end{array}$ & $\begin{array}{l}\text { Known androgenic } \\
\text { alopecia, other papules } \\
\text { on forehead and infra- } \\
\text { orbital region }\end{array}$ & Syringoma \\
\hline $\begin{array}{l}\text { Silva et al., } \\
2009 \text { [13] }\end{array}$ & 26 & $\mathrm{~F}$ & Not reported & $\begin{array}{l}\text { Numerous brown papules } \\
\text { with no associated alopecia }\end{array}$ & $\begin{array}{l}\text { Symmetrically distrib- } \\
\text { uted papules on eye- } \\
\text { lids, neck, axillae, trunk, } \\
\text { abdomen, upper and } \\
\text { lower limbs }\end{array}$ & Syringoma \\
\hline
\end{tabular}




\section{Case Reports in Dermatology}

\begin{tabular}{l|l}
\hline Case Rep Dermatol 2015;7:171-177 \\
\hline DOI: $10.1159 / 000437416$ & $\begin{array}{l}\text { C 2015 S. Karger AG, Basel } \\
\text { www.karger.com/cde }\end{array}$ \\
\hline
\end{tabular}

Deen et al.: Incidental Syringomas of the Scalp in a Patient with Scarring Alopecia

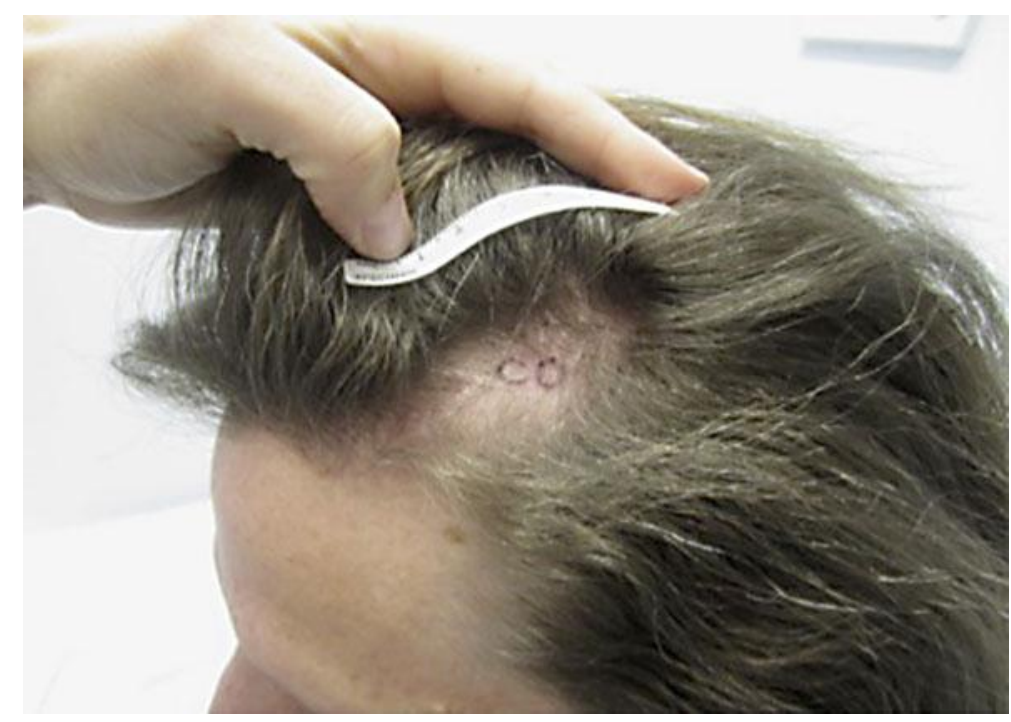

Fig. 1. Left frontoparietal scalp alopecia.

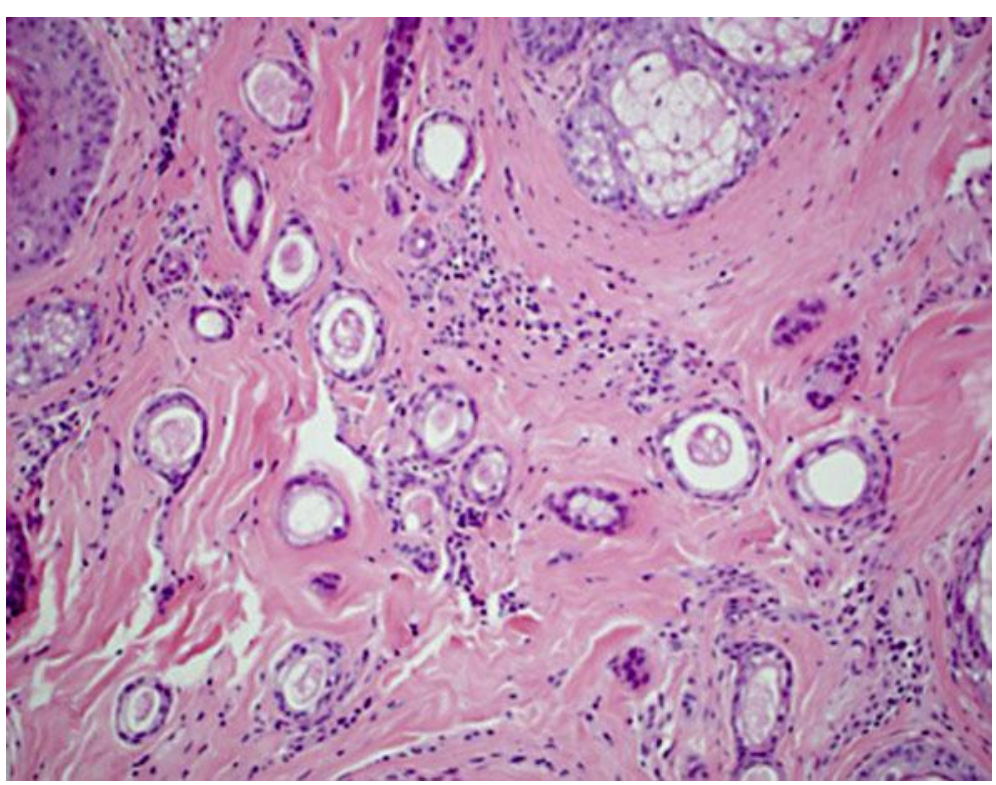

Fig. 2. Characteristic syringoma with double-layered duct-like structures, some with epithelial tails, in a fibrous stroma. HE. $\times 200$. 


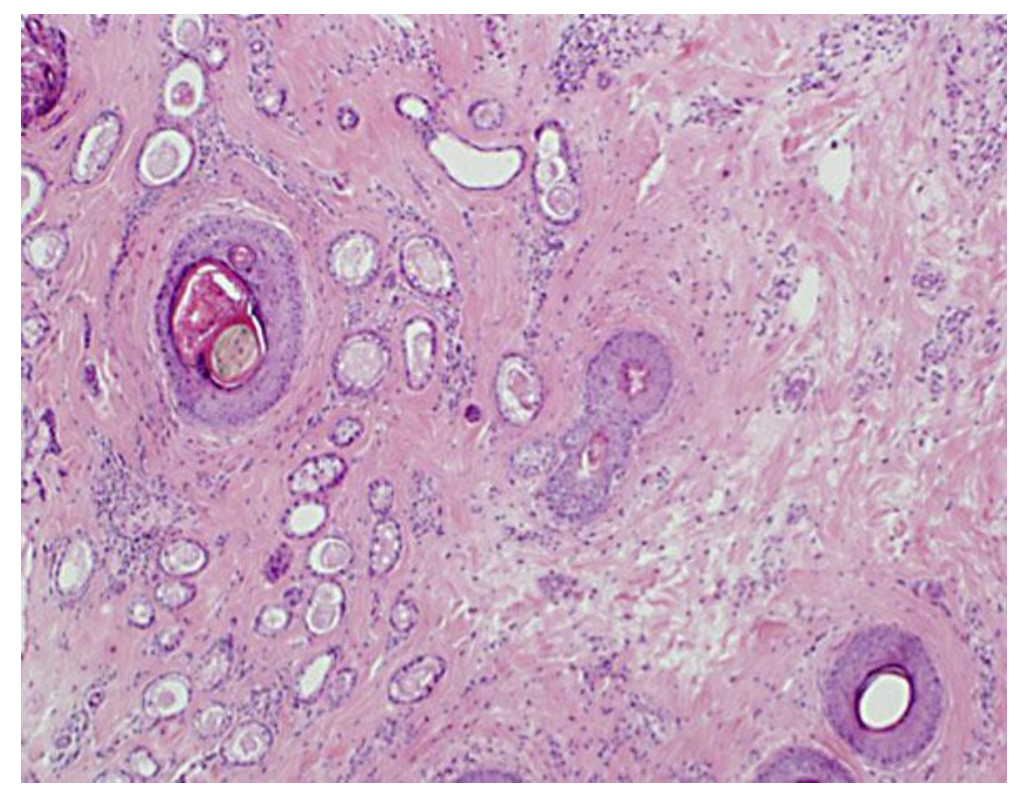

Fig. 3. Syringoma with perifollicular fibrosis. HE. $\times 100$. 